Annales Missiologici Posnanienses t. 24 (2019), s. 31-39

doi: 10.14746/amp.2019.24.2

ORCID 0000-0001-5258-4675

MARTA SIENKIEWICZ

Uniwersytet im. Adama Mickiewicza w Poznaniu

Wydział Teologiczny

\title{
Duch Ameryki Lacińskiej nadzieją dla (nie)chrześcijańskiej Europy
}

Utożsamianie współczesnej Europy z chrześcijaństwem okazuje się ryzykowne. Badacze religijności Europejczyków wykazują, że coraz większy odsetek mieszkańców tego kontynentu nie deklaruje przynależności do chrześcijaństwa ${ }^{1}$, prognozują koniec Kościoła w Europie i zwiastują zanik znaczenia Ewangelii w życiu obywateli tego kontynentu w wyniku sekularyzacji. Zjawisko to określa się ,zmierzchem” czy „nocą” Kościoła. Naukowcy dziedzin humanistycznych, szukając uzasadnienia tego stanu, jako powody podają zróżnicowanie kulturowe, postęp technologiczny, wpływ innych religii, w ostatnim czasie zwłaszcza islamu.

Społeczeństwo europejskie w ostatnich dekadach stało się pluralistyczne pod względem religijnym, etnicznym i kulturowym, a mapa religijności Europy zmienia się $\mathrm{w}$ ciągu kilku lat: najbardziej popularną religią staje się jej brak. Diagnoza problemów sprawia, że Kościół staje przed wyzwaniem, by w społeczeństwie zniewolonym przez interesowność obudzić ducha nadziei, dzięki której możliwe będzie budowanie lepszego jutra. Współczesny świat potrzebuje ludzi wiernych, którzy dzięki wytrwałości i cierpliwości staną się świadectwem, że życie na ziemi ma sens.

\footnotetext{
${ }^{1}$ Na podstawie wyników badań opinii publicznej przeprowadzonych przez Komisję Europejską w ramach projektu Eurobarometr [online]. Wyniki badań dostępne są w Internecie pod adresem: http://ec.europa.eu/commfrontoffice/publicopinion/archives/ebs/ebs_341_en.pdf

W 2014 r. opublikowano dane Instytutu Statystyki Kościoła Katolickiego (ISKK) dotyczące religijności katolików w Polsce; zostały one zestawione z wynikami Eurobarometru obejmującego dane z innych krajów Europy. Wyniki zaprezentowano m.in. w artykule: Religijność w Europie [online]. [dostęp: 27.05.2019]. Dostępny w Internecie: https://www.gosc.pl/doc/2095874.Religijnosc-w-Europie
} 
Krzysztof Pomian w wywiadzie dla Tygodnika Powszechnego (51/2011) stwierdził, że „Europę ukształtowało chrześcijaństwo, kto temu przeczy, zasługuje za pałę z historii”. Nie oznacza to, że europejskość i chrześcijaństwo są ze sobą tożsame, jednak próba zanegowania chrześcijańskiego źródła europejskiej tożsamości zakończy się niepowodzeniem. Chrześcijaństwo dla Europy stanowi jeden z najważniejszych punktów odniesienia - to fakt historyczny. Jednak zaczyna zapominać o tym sama Europa, dlatego należy postawić bezkompromisową diagnozę. Współczesna Europa staje przed wyzwaniem znalezienia sposobu, dzięki któremu chrześcijańskie korzenie nie uschną, a współczesny Europejczyk świadomy tożsamości swojego kontynentu będzie człowiekiem refleksyjnym.

\section{Teologia nadziei - droga zawierzenia}

Rozważania dotyczące kondycji współczesnej Europy zmierzają do pytania o nadzieję. Teologia nadziei jest drogą zawierzenia, a człowiek od początku stworzenia predysponowany jest do noszenia w sobie nadziei pobudzającej do optymistycznego przeżywania otaczającej rzeczywistości i patrzenia na nią. W chwili odkrywania siebie jako istoty ukierunkowanej na rozwój i samorealizację zaczyna doświadczać tej drogi. Jednak coraz częściej jesteśmy świadkami postaw nie tyle smutku, ile wręcz obumierającego człowieczeństwa, czego powodów można doszukiwać się w zaniku nadziei i zamykaniu na wspomniane ukierunkowanie. Sugeruje to, że nie sposób żyć bez nadziei, jak pisze Benedykt XVI, ukazując jej chrześcijańską wizję w numerze 31. encykliki Spe salvi:

Potrzebujemy małych i większych nadziei, które dzień po dniu podtrzymują nas w drodze. Jednak bez wielkiej nadziei, która musi przewyższać pozostałe, są one niewystarczające. Tą wielką nadzieją może być jedynie Bóg, który ogarnia wszechświat, i który może nam zaproponować i dać to, czego sami nie możemy osiągnąć.

Nadzieję tłumaczy się jako oczekiwanie zrealizowania się czegoś pożądanego i ufność, że to się spełni, urzeczywistni, dlatego mówiąc o nadziei, myślimy o psychologicznym zwróceniu się człowieka ku przyszłości, od której oczekuje czegoś, czego jeszcze nie ma, ale także jako o pewnej duchowej dyspozycji, która kieruje ludzką myśl ku Bogu. W Liście do Hebrajczyków odnajdujemy przykład osób, które stały się ludźmi nadziei, ponieważ patrząc w przyszłość, spodziewały się znaleźć ją coraz lepszą i pełniejszą (Hbr 11,1-40).

Uczenie się chrześcijańskiej nadziei sprawia, że doświadczamy, co może, a czego nie jest w stanie zaoferować nam świat, a także, co chrześcijanie, bę- 
dący ludźmi nadziei, mogą zaproponować coraz bardziej zdechrystianizowanej Europie.

Obietnica wiecznego szczęścia, która jest przedmiotem chrześcijańskiej nadziei (KKK 1817), napawa optymizmem i otwiera człowieka na radość będącą darem Ducha Świętego. Teologalna cnota nadziei, rozumiana przez Benedykta XVI jako zawierzenie Bogu, powinna w sposób istotny kształtować postawę człowieka zarówno wobec rzeczywistości ziemskich, jak i spraw ostatecznych. Postawa nadziei w życiu chrześcijanina jawi się jako naturalny efekt eschatologicznego charakteru jego życia i ufności, którą pokłada w obietnicy zbawienia. $Z$ tego powodu nie powinno mu być obce zaangażowanie się w sprawy doczesne, które warunkują spełnienie nadziei wiecznej, ponieważ może ,przez własne zaangażowanie przyczynić się do tego, aby świat był bardziej promienny i ludzki, i aby tak otwierały się drzwi na przyszłość" (Benedykt XVI). Nadzieja musi zawierać decyzję o aktywnym działaniu, która będzie motywowała do podejmowania wszystkiego, co pozwoli osiągnąć zamierzony cel, nawet jeśli pojawią się przeciwności (Kosian 1997, 7).

Szczególnym znakiem nadziei, zauważa Benedykt XVI, jest cierpliwość i wytrwałość, które pozwalają spokojnie znosić ciężar życia, lęk przed przemijaniem i śmiercią. Chrześcijanin umocniony nadzieją na osiągnięcie zbawienia i życie wieczne pewnie wkroczy na drogę naśladowania Chrystusa. W takim rozumieniu nadzieja inspirowana obietnicą przyszłej nieśmiertelności daje siłę duchową, dostarcza chęci do życia, przezwycięża lęk przed śmiercią i uwalnia od niepewności jutra, zgodnie z poleceniem Chrystusa: „Nie troszczcie się więc zbytnio o jutro, bo jutrzejszy dzień sam o siebie troszczyć się będzie. Dosyć ma dzień swojej biedy" (Mt 6,34). Nadzieja jest zorientowana na praktykę, ożywia pamięć o obietnicach Bożych, pozwala pracować na rzecz przyszłości tego świata (Rahner i Vorgrimler 1987, 255), związana jest z oczekiwaniem na zbawienie wieczne, a jednocześnie angażowaniem się w budowę lepszego świata.

Znakiem nadziei chrześcijańskiej jest krzyż, a każdy kto jest w stanie wziąć go na swoje ramiona i przemierzać drogę życia, będzie potrafił dać świadectwo tym, którzy zabłądzili. Cnota nadziei we współczesnym świecie przygniecionym działaniami sekularyzacyjnymi i laicyzującymi staje się remedium na narastający ciężar i szansą na udźwignięcie go.

\section{Aktualność nakazu misyjnego}

Działalność misyjna Kościoła jest zadaniem wynikającym $\mathrm{z}$ jego tożsamości. Kościół powołany jest do głoszenia swojego Założyciela - Jezusa Chrystusa, a Dobra Nowina spisana przez czterech ewangelistów jest źródłem chrześcijańskiego nauczania. Dwaj ewangeliści, św. Mateusz i św. Marek za- 
warli w swoich pismach słowa zmartwychwstałego Jezusa, które mówią o konieczności i skutkach głoszenia Ewangelii oraz przyjmowania chrztu świętego i wiary w Jezusa Chrystusa (Mt 28,19; Mk 16,15-16). To zadanie budowania Kościoła zostało powierzone najpierw apostołom, a później każdemu, kto w imię Trójcy Świętej przyjmuje chrzest.

Człowiek, w trosce o dobro innych, ale także swoje, powinien podejmować refleksję nad własną relacją do nakazu zostawionego przez Jezusa. Współczesny Europejczyk staje przed zadaniem uświadomienia sobie istoty i charakteru Kościoła oraz zadań jego członków. W nakazie Jezusa została zawarta największa tajemnica, jaką Bóg kiedykolwiek złożył człowiekowi. Obserwując otaczającą rzeczywistość, doświadczamy sytuacji, w której Bóg jest pomijany, odpychany, stawiany na dalekim miejscu w życiu człowieka, a religijność utożsamiana ze starością, na którą jeszcze przyjdzie czas. Zaniedbana przez chrześcijan łaska wiary skutkuje niezrozumieniem czy brakiem chęci zrozumienia problemów współczesnego Kościoła, krzywdzącym generalizowaniem, brakiem dialogu, co w efekcie kończy się tragedią - odejściem z Kościoła.

Jako chrześcijanie jesteśmy odpowiedzialni za to, aby każdy mógł stanąć w obliczu wyzwania i podjąć decyzję dotyczącą przynależności do Kościoła. Człowiek nie może być spokojny, póki nie wypełni tego nakazu, póki nie dołoży wszelkich starań, aby Dobrą Nowinę przekazywać światu. Ewangelia powinna być głoszona przez każdego chrześcijanina, ponieważ nakazuje nam to Chrystus, ponieważ bez Boga człowiek jest zgubiony, ponieważ wszędzie są ludzie, którzy mają pragnienie Boga (Blachnicki).

Kościół w obliczu głoszenia Ewangelii staje przed dwoma wymiarami: chrystianizacją, w przypadku braku znajomości Jezusa, i reewangelizacją, w przypadku odrzucenia Chrystusa. Słowa nakazu misyjnego nabierają we współczesnym świecie zupełnie innego charakteru. Obecnie miejsce zamieszkania i pracy każdego chrześcijanina staje się jego terenem misyjnym.

Otrzymany mandat misyjny zachęca do przekraczania granic etnicznych, narodowych czy kulturowych (Nieścior 61). Znaczenie mandatu misyjnego Jezusa najlepiej oddaje wyrażenie z Pierwszego Listu do Koryntian: „Biada mi, jeślibym Ewangelii nie głosił" (1 Kor 9,16).

\section{Ogień Ameryki Lacińskiej nadzieją dla gasnącej Europy}

Odkrycie Ameryki przez Krzysztofa Kolumba w 1492 r. otworzyło nowe możliwości dla Kościoła, otworzyło Amerykę dla Europy, spowodowało zbliżenie do siebie dwóch kontynentów i otwarcie nowego pola działań misyjnych Kościoła (Fąs 12). Przez lata Towarzystwo Jezusowe, zobowiązane swoją 
regułą i przynaglone nakazem misyjnym, wypełniało nowotestamentalne posłannictwo na terenach Nowego Świata. Nastąpiło niezwykłe zjawisko, nigdy wcześniej niemające miejsca spotkanie dwóch światów - Nowego i Starego ${ }^{2}$.

Czas pierwszego głoszenia Ewangelii na terenach Nowego Świata zbiegł się z czasem kolonizacji dokonywanej przez hiszpańskich konkwistadorów. Literatura epistolarna ${ }^{3}$ misjonarzy Towarzystwa Jezusowego relacjonuje przebieg procesu chrystianizacji i ewangelizacji, powstawania redukcji jezuickich, które stały się głównym miejscem misyjnej działalności. Dorobek ten jest źródłem wiedzy, który przyczynił się do wyciągnięcia wniosków dotyczących ewangelizacji.

Badacze sytuacji Kościoła zastanawiają nad jego obecnym obrazem. Kościół w Europie Zachodniej nazywają Kościołem pogan. To mocne stwierdzenie ma określać chrześcijan, którzy są nimi tylko z nazwy. Świadomość zatracania chrześcijańskiego ducha powinna prowadzić do podejmowania refleksji, dokąd zmierza Kościół. Jego członkowie coraz rzadziej przyznają mu prawo do interpretowania Ewangelii, głoszenia obligatoryjnej nauki moralnej (Zając 62) czy zajmowania stanowiska w sprawie nauki społecznej. Dzisiaj chrześcijaństwo, aby zostało przyjęte, musi być atrakcyjne. Jednak należy zadać pytanie, czy trzeba się gimnastykować w celu pozyskiwania nowych wiernych czy raczej cierpliwie odkrywać swoje bogactwo (Zając 64). „Nie da się napoić osła, który nie chce pić" (Zając 68).

Papież Jan Paweł II określił Amerykę Łacińską jako kontynent nadziei, jednocześnie apelując, aby stała się ona kontynentem życia (Jan Paweł II). Żywił nadzieję, że po pierwszym amerykańskim Synodzie Ameryka rozkwitnie, by dawać świadectwo wiary innym kontynentom świata.

Jego następca nadzieję upatrywaną w tym kontynencie argumentował wiarą w Boga, który jest miłością i który ukazał swoją twarz w Jezusie Chrystusie. Jako niezwykłe bogactwo tego kontynentu, które czyni z niego kontynent nadziei, określił siłę i radość wypływającą z wiary oraz pokój otrzymany od Chrystusa. Wyraził przekonanie, że pomoc w reewangelizacji - przede wszystkim Europy - może przyjść od narodów, które poprzez swoje świeże przeżywanie wiary mogą mieć znaczący wpływ na kształtowanie się religijności i duchowości we współczesnym świecie (Benedykt XVI).

\footnotetext{
${ }^{2}$ Wskutek zderzenia kultury europejskiej z kulturą autochtoniczną powstała nowa kultura nazywana kulturą redukcji. Była ona kulturą Indian z przejętymi elementami wiary chrześcijańskiej.

${ }^{3}$ Największym źródłem bezpośredniej wiedzy o chrystianizacji w Nowym Świecie jest zbiór listów nadsyłanych przez misjonarzy. Publikacja Tomasza Szyszki SVD pt. Listy różne ku chwalebnej ciekawości i chrześcijańskiemu zbudowaniu shuzace jezuickich misjonarzy z Ameryki Hiszpańskiej, wydana przez Wydział Teologiczny UAM w Poznaniu w 2016 r., zawiera wszystkie zachowane relacje misyjne wraz z obszernym historyczno-społeczno-geograficznym komentarzem.
} 
Wybór na papieża kardynała z Ameryki Południowej spowodował zwrócenie oczu całego świata na ten kontynent, który może być szansą dla pozostałej części świata na obudzenie chrześcijaństwa. Dzięki kulturze i świeżości Ameryka Łacińska jest nadzieją dla Kościoła w Europie, który obecnie przechodzi przez meandry sekularyzacji. Doświadczenie tego kontynentu może przywiać ducha świeżości w codziennym odnawianiu decyzji o wyborze Jezusa.

\section{Wobec współczesności}

Ewangelia pozostaje niezmienna, choć zmienia się świat, któremu ma być głoszona. W Kościele na przestrzeni ostatnich dekad wiele mówiono na temat nowej ewangelizacji jako zbioru działań mających za zadanie dotarcie z Dobrą Nowiną do ludzi obecnej epoki. Jan Paweł II twierdził, że ma ona polegać na nowej gorliwości, nowych metodach i nowym sposobie głoszenia i dawania świadectwa (Jan Paweł II 18).

Od czasów Soboru Watykańskiego II rozumienie pojęcia nowej ewangelizacji przechodziło przez kilka etapów. W dokumentach Kościoła podejmowano problematykę dotyczącą kontynuowania drogi, którą Kościół przebył przez prawie XX wieków, oraz nadania priorytetu głoszeniu Ewangelii w sposób odnowiony i skuteczny. W Dekrecie o działalności misyjnej Kościoła ojcowie soborowi zaznaczyli, że zadanie głoszenia Ewangelii ,jest wszędzie i w każdej sytuacji jedno i to samo, chociaż zależnie od okoliczności, jest w różny sposób wykonywane" (Ad gentes divinitus 6).

W Europie, która zakorzeniona jest w chrześcijaństwie, bardziej właściwe będzie używanie pojęcia reewangelizacji jako sposobu na odbudowanie mocnego Kościoła. Istotne słowa dotyczące cierpliwości, będącej wyrazem nadziei, zawarł w swojej adhortacji papież Franciszek: „Czasem Kościół jest jak ojciec syna marnotrawnego, który pozostawia drzwi otwarte, aby mógł on wejść bez trudności, kiedy powróci” (Franciszek 46).

Chrześcijaństwo jako religia totalna, dająca się wyrazić w każdej kulturze, charakteryzuje się oczekiwaniem i otwartością dla wszystkich, którzy odkrywają Prawdę. Poznanie autentycznych wartości danej kultury i przyjęcie tego wszystkiego, co jest w nich dobre, oraz ubogacanie ich Ewangelią jest podstawowym założeniem procesu inkulturacji, która powinna stać się konieczną metodą nowej ewangelizacji. Inkulturacja jest relacją pomiędzy ziemią (kulturą) a ziarnem (Słowem; Różański 33) . 
Bywa, że człowiek czuje się, jakby wsiadał do małej łódki i wypływał na głęboki ocean, któremu na imię Europa, pełny skarbów i niebezpieczeństw. Poruszanie się po tej przestrzeni wymaga wysiłku i zaangażowania, a przede wszystkim świadomości, że każda decyzja niesie za sobą konsekwencje. Zadanie odnalezienia siebie na kartach Ewangelii, by autentycznie, z zaangażowaniem nieść innym Chrystusa, zwłaszcza gdy trzeba iść pod wiatr, staje się obowiązkiem każdego, kto dokonuje wyboru, by wziąć krzyż i naśladować Mistrza - Jezusa Chrystusa. Wielu zastanawia się, dokąd zmierza Europa.

Leszek Kołakowski zauważał, że Osoba i nauki Jezusa Chrystusa nie mogą zostać wykorzenione z naszej kultury, jeśli zakładamy, że kultura ta ma nadal istnieć i się tworzyć. Zatem należy jasno stwierdzić, że chrześcijaństwo jest fundamentem naszej europejskiej kultury, co więcej, jest warunkiem dla jej przetrwania (Zięba 48).

Kościół staje przed wielkim wyzwaniem dotyczącym przekazywania Dobrej Nowiny. Adhortacja papieża Franciszka, która podsumuje synod ds. Amazonii może okazać się kluczowym dokumentem w dalszym rozumieniu, przeżywaniu i kontynuowaniu przekazywania chrześcijańskiej wiary. Kościół potrzebuje także jedności przekazywanej nauki, by we wszystkich krajach na świecie, gdzie mieszkańcy określają siebie jako katolików, była przekazywana tożsama nauka. Kultura, która jest bardzo ważną przestrzenią ludzkiej egzystencji, może ukazywać człowiekowi sposób przeżywania i budowania swojej relacji do Boga. Różnorodność kulturowa może zatem przyczynić się do odnowienia, podjęcia refleksji czy działań, które pozwolą na nowo spojrzeć na wiarę, a przede wszystkim ją umocnią.

Należy jednak pamiętać, że wybór Jezusa określa człowieka. Maksyma św. Augustyna: „Raz wybrawszy, ciągle wybierać muszę”, zawarta w jego $W y$ znaniach, wskazuje na nieustanną konieczność wierności powziętej decyzji i ćwiczenie się w gotowości do zgodnych z wyborem reakcji i działań. W konfrontacji z innymi kulturami i religiami współczesny chrześcijanin musi mieć odwagę proponować innym Chrystusa.

\author{
SPIRIT OF LATIN AMERICA \\ AS A HOPE FOR (UN)CHRISTIAN EUROPE
}

\title{
Abstract
}

The article indicates the disappearance of Christianity in Europe. The article refers to Christian hope as an inspiration and motivation to undertake evangelization activities. The article contains references to popes who see help for secularized Europe 
in Latin America and the people of this continent. The text emphasizes the importance of culture in experiencing religion and building relationships with God. It signals that re-evangelization is needed in modern Europe, which will lead to the rebuilding of Christian identity. The text also emphasizes that Christianity is a religion for everyone, and Christian teaching should be uniform.

Keywords: Latin America; re-evangelization; Europe; Christianity; spiritual crisis; Christian hope; missions; evangelization; Church in Europe; culture

Słowa kluczowe: Ameryka Łacińska; reewangelizacja; Europa; chrześcijaństwo; kryzys duchowy; nadzieja chrześcijańska; misje; ewangelizacja; Kościół w Europie; kultura

\section{BIBLIOGRAFIA}

Eurobarometr. Dostęp 19 maja 2019. http://ec.europa.eu/commfrontoffice/publicopinion/archives/ ebs/ebs_341_en.pdf

Ad gentes divinitus. Dostęp 18 maja 2019. https://kosciol.wiara.pl/doc/492068.Ad-Gentes

Benedykt XVI. Encyklika Spe salvi. Dostęp 20 maja 2019. http://w2.vatican.va/content/benedict-xvi/pl/encyclicals/documents/hf_ben-xvi_enc_20071130_spe-salvi.html

Benedykt XVI. Wiara w Boga-Miłość uczyniła Amerykę Lacińska , kontynentem nadziei” - homilia wygtoszona 13 maja 2007 r. w Aparecidzie podczas Mszy Świętej rozpoczynającej V Konferencję Ogólna Episkopatu Ameryki Łacińskiej i Karaibów, w trakcie podroży apostolskiej do Brazylii 9-14.05.2007. Dostęp 11 listopada 2019. https://opoka.org.pl/biblioteka/W/WP/benedykt_xvi/homilie/brazylia_aparecida_13052007.html

Blachnicki, Franciszek. Wielki Nakaz Misyjny Chrystusa. Dostęp 20 maja 2019. www.blachnicki. oaza.pl/conf/agape/rnz5.html

Franciszek. Adhortacja Evangelii gaudium. Dostęp 20 maja 2019. https://opoka.org.pl/biblioteka/W/WP/franciszek_i/adhortacje/evangelii_24112013.html

Fąs, Ludwik. „Patronat misyjny” NURT SVD (2004) 1: 7-48.

Jan Paweł II. Adhortacja Pastores Dabo Vobis. Dostęp 20 maja 2019. https://w2.vatican.va/content/ john-paul-ii/pl/apost_exhortations/documents/hf_pl-ii_exh_25031992_pastores-dabo-vobis. html

Jan Paweł II. Niech kontynent nadziei będzie także kontynentem życia - homilia wygłoszona 23 stycznia 1999 r. podczas Mszy Świętej w bazylice Matki Bożej z Guadalupe w Meksyku w trakcie podróży apostolskiej Jana Pawła II do Meksyku i Stanów Zjednoczonych 22-28.01.1999. Dostęp 10 listopada 2019. https://opoka.org.pl/biblioteka/W/WP/jan_pawel_ii/homilie/guadalupe_23011999.html

Katechizm Kościoła Katolickiego. Poznań: Pallottinum, 1992.

Kosian, Józef. Filozofia nadziei. Wrocław: Wydawnictwo Uniwersytetu Wrocławskiego, 1997.

Nieścior, Leon. „Ojcowie Kościoła wobec starożytnych kultur.” Lumen Gentium. Zeszyty misjologiczne (2013) 1: 49-61.

Pismo Święte Starego i Nowego Testamentu, Częstochowa: Święty Paweł, 2008.

Rahner, Karl. Vorgrimler, Herbert. Mały słownik teologiczny. Warszawa: Instytut Wydawniczy Pax, 1987.

Różański, Jarosław. „Założenia inkulturacji” Lumen Gentium. Zeszyty misjologiczne (2013) 1: 7-33. 
Seweryniak, Henryk. Teologia fundamentalna. Vol. 1. Warszawa: Biblioteka „Więzi”, 2010.

Zając, Marian. „Reewangelizacja skutecznym antidotum w duszpasterstwie Europy Zachodniej.”

Europa dla Chrystusa - Chrystus dla Europy. Reewangelizacja cywilizacji zachodniej. Red. Bogdan Giemza. Kraków: Wydawnictwo Salwator, 2009.

Zięba, Maciej. Kłopot za kłopotem. Katolik w dryfującej Europie. Poznań: W drodze, 2015.

Marta Sienkiewicz, doktorantka na Wydziale Teologicznym Uniwersytetu im. Adama Mickiewicza w Poznaniu. 
